\title{
Infection complication rate in kidney transplanted patient in Mongolia in last 3 years
}

\author{
Khishgee Tseren, Bayan-Undur Dagvadorj, Od-Erdene Lkhaakhuu, Bat-Ireedui Badarch, Udval Batkhuu
}

Organ Transplantation Center, First Central Hospital of Mongolia, Ulaanbaatar, Mongolia

Background: Infection remains a significant cause of morbidity and mortality in renal transplant recipients. In Mongolia, mean cause of kidney graft dysfunction is infection.

Methods: We studied a total of 72 patients who underwent a kidney transplant from 2017 to 2019. Demographic data was investigated as follows: age, sex, region from transplant center, body mass index, bacteriology culture post-kidney transplantation of early period (1-6 months) and late period (more than 6 months), epidermal growth factor receptor, induction and maintenance immunosuppressive medication, number of hospitalization, surgical complication, vaccination, etc.

Results: Overall mean age of subjects was $34.6 \pm 3.5$ years; females were $14(19.4 \%)$ and males were $58(80.6 \%)$. With living donor recipients were 59 (81.9\%), deceased donor recipients were 13 (18.1\%). Region location from transplantation center was 40 patients (55.6\%) living in Ulaanbaatar City and 32 patients (44.4\%) living so far from Ulaanbaatar in region. The number of early-period infection complications was 81 bacterial (98.8\%) and one virus (1.2\%). From bacterial infections, urine tract infections were 26 (32.1\%), respiratory infections were $52(64.2 \%)$, and tuberculosis, pyodermatitis, pneumonia, and cytomegalovirus infection were one (1.2\%), respectively. From late-period 67 infections, 64 (95.5\%) were bacterial, three (4.5\%) were virus infections, and from all this $23(35.9 \%)$ were urine tract, $32(50.0 \%)$ were respiratory, four $(6.3 \%)$ were pyodermatitis, and H1N3 virus etiology pneumonia, herpes zoster, varicella zoster were one (1.5\%), respectively. From all of 72 infected patient, graft loss was one patient. Main bacterial etiology in both periods was Escherichia coli, Klebsiella pneumoniae extended-spectrum $\beta$-lactamases, etc. Number of hospitalization in infected 26 patients was 46.

Conclusions: Infection complications in Mongolia for post-kidney transplant are still common, particularly urinary tract infections.

Corresponding author: Khishgee Tseren

E-mail: Ts.Khishgee@fchm.edu.mn

(c) The Korean Society for Transplantation

This is an Open Access article distributed under the terms of the Creative Commons Attribution Non-Commercial License (http://creativecommons.org/licenses/by-nc/4.0/) which permits unrestricted non-commercial use, distribution, and reproduction in any medium, provided the original work is properly cited. 